\title{
Power Repertoires and the Transformation of Tanzanian Trade Unions
}

\author{
Gundula Fischer, Tumaini University, Tanzania
}

\begin{abstract}
Tanzania's turn away from socialism resulted, among other things, in a liberalization of trade unions. Based on labour's new potential, unionists have revised their inventory of collective action, while at the same time clinging to established arrangements. This anthropological article explores how union leaders and their development partners view the transformation. It shows where respondents see avenues for strengthening their position and constraints in reaching their goals. An approach based on social movement theory, namely the concept of 'repertoires', is applied here in order to interpret and discuss the data. This approach is useful, although it needs to be supplemented by an investigation of actors and the overlapping solidarities they construct.
\end{abstract}

\section{KEYWORDS}

Liberalization, social movement theory, trade unions, Tanzania

\section{Introduction}

'In the past we were part of the one-party system. We were united and strong. The liberalization of trade unions has affected our work negatively', a high-ranking Tanzanian trade unionist says in an interview. A colleague of his comes up with a different assessment: 'We have more power than before. We feel that we can bring about more change'. These statements only apparently contradict each other. In fact, they adequately outline the transformation the Tanzanian labour movement has undergone in the past two decades. At the beginning of the 1990s, trade unions were detached from the former socialist one-party apparatus and became (at least nominally) independent. As a result, proven strategies for furthering interests have become less effective or obsolete. At the same time, other means of collective action are being devised or revived. The unions do not stand alone in their endeavours. They forge their strategies and activities in exchange with (among others) a small group of development partners, including Western trade unions, development agencies and the ILO (International Labour Organization).

Based on ethnographic interviews, this article explores the transformation of Tanzanian trade unions. It analyses the views of a selected group of union leaders and their international development partners with respect to labour power and strategies in a changing political and economic environment. Special emphasis is put on two questions: What possibilities do respondents see for unions to strengthen their position? What constraints do unions face in their attempts to gain or exercise power? In the following section I will briefly outline why the concept 
of 'repertoires' - initially introduced by Tilly $(1984$; 1993) - lends itself to an analysis of the Tanzanian labour movement from an anthropological perspective. Thereafter (section three), I will sketch the history of Tanzanian unions as a backdrop for current developments. In section four, I will remark on the research methodology and present my data. Section five will discuss the findings in relation to the concept of power repertoires.

\section{Anthropology, Union Power and Transformation}

In recent decades, cultural anthropologists have developed a growing interest in how workers organize unions. Using their discipline's research methods (participant observation, ethnographic interviews), they have addressed diverse topics, such as how the representation of class intersects with questions of gender, race and religion (see Brodkin 2010 for an overview), or how the local context in which unions operate is shaped by and feeds back into global processes (e.g. Otanez 2010). An important concern has been to give voice to the inside perspectives of union activists (Erem and Durrenberger 1997) - a point which has informed the presentation of my data below. Although there is a strong regional focus on the US, some studies from other countries exist (see Durrenberger and Reichart 2010). In their investigation of organized labour, anthropologists have referred to several theoretical approaches, among them political ecology, collective action and social movement theory (see Durrenberger 2007). However, the elaboration of these approaches within the anthropology of unions is not yet advanced, probably because the sub-discipline is still in its infancy. Case studies are needed in order to be able to discuss the usefulness of the concepts at hand.

This paper is based on an approach from social movement theory. The historian Tilly sowed the seeds for it in the late 1970s, by introducing the concept of 'repertoires'. In a discussion of social movements, he describes 'the set of means [...] effectively available to a given set of people as their repertoire of collective action' (1984: 307). A repertoire is open to variation and change. New strategies are invented, available means adapted and inappropriate means abandoned (1984: 307-309). Repertoires are contentious since they constitute ways in which groups 'make and receive claims bearing on each other's interests' (Tilly 1993: 265). Cohen and Rai relate this concept to social movements on a global scale. They state that social movements are in transition from a national era, marked by strikes and public rallies, to a transnational solidaristic era, with a new repertoire of social summits and consumer boycotts (2000: 15). The applicability of this statement to Tanzania is questioned in section five of this paper. Focussing on unions, Piven and Cloward (2000) modify Tilly's approach and hint at a discrepancy between the shifting power potential created by institutional arrangements and the popular strategies (repertoire) through which power can be realized. The discrepancy emerges from two features of the repertoire: first, the repertoire is 'shaped by multiple relations beyond the particular power relations at issue', such as family, church or community (2000: 414). Second, it becomes 'imprinted in cultural memory and habit' and persists (even if inappropriate) until new strategies emerge (2000: 414). The realization of power is thus facilitated or constrained by diverse beliefs, habits and solidarities.

Piven and Cloward's concept of 'power repertoires' - it opens up an avenue for the anthropological study of union transformation. Being holistic in nature, it allows one to evaluate perceptions and actions on the micro-level, and how they relate to processes on the macro-level. For instance, economic liberalization and the introduction of multi-party democracy create new 
power possibilities which workers may tap (or may not tap) through their repertoire. Furthermore, Piven and Cloward push the study of unions to its intersection with other forms of social organization (such as ethnicity, gender and family), as the assumption is that repertoires bear a relation to them. This article attempts to use this approach for understanding the changes Tanzanian unions have passed through in the last two decades. Its advantages and limitations will become visible in section five. The following chapter provides a sketch of Tanzanian labour history, with a focus on repertoires and power perceptions (wherever these are accessible in the literature).

\section{Short History of the Tanzanian Labour Movement ${ }^{l}$}

The history of the Tanzanian labour movement is often seen as a sequence of three distinct periods related to different political systems (e.g. Mukandala 1999). The first period comprises the time under British colonial administration, when labour protests emerged and unions succeeded in becoming officially registered. Independence in 1961 marks the beginning of the second period, in which unions went into opposition to the new Tanzanian government. Through legal measures, they were successively incorporated into the socialist party organization. In the mid-1980s, Tanzania turned away from socialism. Since then it has undergone several structural adjustment programmes and introduced multi-party democracy. The liberalization of unions falls into this third period. In what follows, I will sketch each period, acknowledging continuities in spite of changes in the political environment.

The beginning of the Tanzanian labour movement can be traced back to the late 1920s. At that time workers formed organizations, which in part resembled elitist professional associations, and in part carried out strikes for higher wages (Shivji 1986b: 158; Mukandala 1999: 3). The colonial government tried to silence labour unrest through a law that legalized the establishment of unions and would control them. However, insufficient organizational skills on the side of the workers, and repressive attitudes on the side of the government prevented the registration of effective unions (Chambua 2004: 21). Resistance against poor working conditions was mainly channelled through letters, petitions or individualized protests (Mukandala 1999: 4). After 1937, a wave of dockworkers' strikes 'marked the beginning of industrial instability' and culminated in the general strike of 1947 'which spread like bushfire throughout most of the towns up country' (Mihyo 1983: 14-15). As an immediate result, the first five trade unions were registered, with an apex organization following in 1955. Although the unions initially lacked a clear political position, they later joined hands with TANU (Tanganyika African National Union), the national movement for independence. This was a 'marriage of convenience' (Mukandala 1999: 9) in which each party supported the other. TANU appealed to people to join in workers' strikes. Workers, on the other hand, became the torchbearers of nationalist ideas, especially when going back to their home towns (Mihyo 1983: 47-48).

Shortly before and after independence (1961), strikes increased and finally disrupted the 'marriage of convenience'. As Mukandala states, 'trade unions were the only organized centers of power' outside the state structures and thus threatened the new TANU regime (1999: 11). Union leaders viewed strike action as an integral part of their organizational identity (Mihyo 1983: 6566). Their demands were related to higher wages and the immediate Africanization of top positions in industries and administration. TANU, however, wanted to replace non-African employees gradually. As labour unrest continued unabated, the government passed a host of laws, 
which brought unions under their control and restricted their right to strike. In 1964, the unions' apex organization was dissolved and re-founded as an affiliate of the ruling party. Top executives of NUTA (National Union of Tanganyika Workers) were to be appointed by the Tanzanian president himself (Chambua 2002: 27). In spite of this incorporation, struggles between employees and employers went on - the government being the biggest employer after the nationalizations that followed the Arusha Declaration (1967). Party documents inspired workers and helped legitimize their actions. A common strategy was to lock out managers or to employ TANU branches (which were established at company level in 1969) as 'watchdogs' against the management (Nyalali 1975: 207-212, Masanja 1990: 228). The government temporarily sympathized with these ideology-laden struggles, but put an abrupt end to them in 1973 . The grip on trade unions was again tightened, leading in 1978 to the establishment of a sole trade union (JUWATA) operating under the constitution of the party (Chambua 2002: 30). In the light of these developments, it has been debated whether the successive incorporation of unions actually silenced workers' protests or resulted in devising new channels of resistance. Shivji claims that through legal restrictions 'state control of the working class reigned supreme' (1986b: 8). Similarly, Mukandala speaks of the 'total power of control' the party had over the unions (1999: 50). Masanja rejects the idea of a 'death of the trade union movement [...] unless workers' activities are reduced to the legal, institutional structures' (1990: 211). He hints at hidden forms of resistance such as absenteeism, go-slows or individual approaches to managers (1990: 229). Workers retained their influence on management decisions through patrons within the company, as well as through personal access to high-ranking politicians - both often grounded in ethnic or kin relations (Fischer 2006). Issues of conflict were deductions and the timeliness of payments, unequal treatment and discrimination at work, the distribution of loans, and matters of work organization (Masanja 1990, Fischer 2006). In state-owned companies the Presidential Standing Committee on Parastatal Organisations centrally set and controlled the wages. Increases were made by government directive and announced on May Day by the Tanzanian president. In reaction to wage control, some workers employed the strategy of udokozi (theft in small amounts), especially when real income declined tremendously in the 1980s (Masanja 1990: 229, Fischer 2006: 77-81). Although an overemphasis on strikes and overt militancy has been pointed out early in the analysis of African labour movements (Cohen 1980), further documentation of Tanzanian repertoires of hidden action is scarce.

As early as 1982, the relationship between JUWATA, the sole union, and the party (renamed and re-established as Chama Cha Mapinduzi (CCM in 1977) was ridden by conflicts JUWATA demanding organizational autonomy and freely elected leaders, CCM not allowing the union to get away from party supremacy (Mukandala 1999: 17-19). In the face of a severe economic crisis combined with internal and external pressures for political reforms, the Tanzanian government turned away from socialism in 1985. A side effect of multiparty democracy was the independence of unions in 1991. Since then, unions have been swinging between two opposite poles - continuous control by the government and efforts to establish themselves as autonomous civil society organizations. According to Mukandala, there 'have been deliberate manoeuvres to delay the delinking process so as to keep the unions indirectly under the influence of the ruling party and its government' (1999: 51). It was not until 2000, after several organizational dissolutions and re-registrations, that the present federation, the Trade Union Congress of Tanzania (TUCTA), was founded with 14 sectoral unions affiliated to it. A new membership concept (voluntary membership instead of forced membership as under socialism), as well as the privatization of parastatals, and retrenchments in private and government 
institutions have left some sectoral unions with fewer members than before. Others, especially in the fields of education and health (where a mushrooming of private companies is taking place), have managed to attract a considerable number of new members (Chambua 2004: 10-11).

Tanzania's economic transformation was based on a series of structural adjustment programmes. As a consequence, real wages declined to an extent that workers lost the privileged income position they had previously enjoyed, and became 'proletarianized', as Musoke writes (1996: 65). On top of that, the government removed subsidies and price control, and introduced user fees for basic social services (such as health, education and water). While workers had previously managed to survive on low wages, they became forced to engage in additional incomegenerating activities (Chambua 2002: 104-105). In some areas of the labour market a casualization has taken place, such as in the plantation sector where in the period between 1994 and $2001,50 \%$ of the permanent workers were turned into temporary employees (Chambua 2004: 13-14). New investors have created employment, but it tends to be flexible. Various sources speak of an attitude hostile to unionized workers in the private formal sector (e.g. ICFTU 2006). Unionists have seen the government as siding with new employers so as to attract more investment (Chambua 2004: 6) or even as accepting exploitative employment conditions (McQuinn 2009: 1). However, unions still favour defending the public sector, to the disadvantage of a growing number of private and informal workers. This could be a result of labour's past entanglement with the state (Chambua 2004: 1).

Interestingly, soon after their detachment from the party, unions reverted to their tactics of pressurizing through strikes. In 1994, for instance, the federation organized a nationwide general strike. The trigger was an unfulfilled promise by the Tanzanian president to increase government wages and salaries. Chambua calls the event a 'success story in the country's trade union history since 1964' - and this in spite of massive government threats (2002: 100). Again in 2010 TUCTA prepared (but finally shelved) a general strike to push for public servants' complaints over low and delayed payments. The three declared priorities of the unions are all targeted at the government (as legislator and employer). They are: pay increases in the private and public sectors (linked to increases set by the minimum wage boards), income tax reductions, and an adequate level and management of old age pensions. Although most attention has centred on the first point, the government has been reluctant to give in to workers' demands, claiming a restricted state budget and the necessity to create an investor-friendly environment. This position has caused unionists and journalists to repeatedly charge politicians with corruption, profligacy and 'obscene opulence', while at the same time denying workers a living wage (Ulimwengu 2010: 17, Raia Mwema 2011: 4). Another smouldering conflict has been the national privatization exercise. Unions have protested, and at times even legally sued the Parastatal Sector Reform Commission for selling off 'their' companies - without success (see Fischer 2006: 137-138). Retrenchments, flexible employment patterns and higher workloads are castigated, as well as restrictions in access to public goods (such as water and transport) if privately managed (Komba 2010: 23). In the ideological sense, some workers and union cadres have viewed privatization as a reversal of the Ujamaa tenet 'to make the factories ours' (viwanda ni vyetu) ${ }^{2}$ and thus as expropriation, in respect not only of legal but also of cultural ownership (Fischer 2003: 344-345). Foreign-owned enterprises established after liberalization (such as multinationals in the mining sector) are criticized for receiving tax exemptions while offering only meagre earnings and short term contracts to the local population. TUCTA called upon the government to review the tax scheme and to relieve public servants and farmers instead (The Citizen 2011: 2). To sum up: in the past few years, workers' grievances have mainly been related to low (minimum) wages, 
payment arrears, a high income tax burden, inadequate pension funds and poor terms of employment in privatized or newly set up private companies.

The new labour law (Employment and Labour Relations Act 2004) reduces the previously substantial power of the registrar of trade unions, and some of the complicated procedures unions had to go through to legally call for a strike. However, those taking part in legal strikes are not protected from retribution, and more sectors than before are deemed strategic with restrictions preventing workers from practising any industrial action (see ICFTU 2006). These legal weaknesses, as well as workers' issues in general, could be addressed by party politics, but none of the political parties seeks to represent labour. While some of the old union cadre retain their relationship with the ruling party (CCM), radical unionists do not engage with opposition parties. Chambua states that some opposition leaders do not trust the unions, as they view them as being still affiliated with or receiving instructions from the CCM (2002: 131). Labour representation in the political arena is still weak. Liberalization has knocked unions off their pedestal as part of a political mass organization. The new role of unionists is to defend the formal sector, which is relatively small as compared to larger numbers of workers in agriculture and in the informal economy. ${ }^{3}$ The challenges unions face and the means they have at their disposal are discussed in the following section.

\section{Findings: Strategies and Restrictions}

Between December 2007 and February 2009 I interviewed nine union leaders on the national level and on the level of one region (the Lake Zone comprising Mwanza, Mara, Shinyanga and Kagera). Access to respondents was established through snowball sampling. All interviewees were in leading positions either in the apex organization TUCTA (Trade Union Congress of Tanzania) or in the sectoral unions TUICO (Tanzania Union of Industrial and Commercial Workers), CHODAWU (Conservation, Hotels, Domestic and Allied Workers' Union) and COTWU (Communication and Transport Workers' Union of Tanzania). The selection of these organizations was guided by my interest in union activities in the informal sector. TUICO, CHODAWU and COTWU have been especially engaged in this field. An analysis of informal sector activities will be published elsewhere.

Apart from these officials, I interviewed three experts from international development organizations. Over the past few years they have supported the unions through training, funding and staff. Their assessment of the labour movement - made from a detached but informed position - helped to clarify important aspects. The small number of respondents in this group is due to the fact that only a few international organizations continuously support the unions (see 4.1.2) and maintain representatives in Tanzania. All respondents (unionists and experts) were asked to talk about the transformation of unions and efforts to organize the informal sector. Questions were open-ended (see Spradley 1979 for ethnographic interviews); all interviews (except for two with experts) were conducted in Swahili.

The views captured in the interviews are grouped into two categories: first, strategies the respondents see as furthering collective interests, and second, restrictions to effectively defending workers' interests. In what follows, I retain these categories, although strategies (4.1) are discussed with their specific limitations. With regard to the first category, respondents spoke of five strategies to exercise or increase union power: strikes, cooperation with international organizations, the recruitment of new members, a better involvement of marginalized members, 
and the need to raise unionists' educational standards in order to improve leadership and negotiations. The next part discusses these strategies in detail.

\subsection{Strategies to Further Collective Interests}

\subsubsection{STRIKES}

In the past, when unions were part of the political party, they had no room to decide for themselves, a unionist says. Strikes were subject to complex legal procedures and difficult to organize. However, personal avenues were available, such as to approach important members of the political party who would make employers tremble, he states, and continues: Now with the new labour law and the possibility to strike, employers may resist but finally have to give in.

Not all unions are equally active in organizing strikes. When respondents took up this topic, they mainly referred to actions by TUICO (Tanzania Union of Industrial and Commercial Workers) and Tanzania Teachers' Union (TTU). 'I have seen that TUICO often tries to be close to the workers and tries to defend them', an international expert says. She depicts how in 2008 TUICO called for a strike at the South African supermarket chain Shoprite, and later managed to resolve the conflict through a committee of employees, employers and union representatives. Another example brought up in favour of TUICO is the National Micro Finance Bank strike of 2008, in which workers successfully demanded terminal benefits after their bank had been restructured. Less effective, but intensively covered by the media, are the continuous struggles between teachers and the government as their employer. At the core of this conflict are salary payment arrears going back several years. When the teachers announced strikes in 2008, the government blocked them through the Labour Court. In the same year, the Tanzanian High Court declared the strikes legal and asked the government to immediately refrain from harassing the teachers involved in the actions. The government 'still thinks that it can control the unions', a development partner comments, and adds: the government put the new labour law in place, but it 'does not really want to use the system'. Even in 2009 and 2010 the problem of payment arrears persisted.

Through strikes you can measure how far different unions have transformed themselves, an expert says. The example given is food processing, where workers in the same company may belong to different sectoral unions. Plantation workers are members of Tanzania Plantations and Agricultural Workers Union (TPAWU); their colleagues in the factory who process the produce are part of Tanzania Union of Industrial and Commercial Workers (TUICO). As TUICO is more offensive, plantation workers have at times demanded the right to join it. The inability of some union leaders to channel workers' grievances through negotiations and planned strikes, together with the competition among sectoral unions, have led to violent riots, the expert concludes. Even more fundamental conflicts within the labour movement became visible on May Day 2010. The federation had called upon sectoral unions to support a countrywide strike to add weight to the demands of public servants. Affiliates in favour of the strike and those against it held separate May Day celebrations in Dar es Salaam. Different attitudes towards the government were seen as causing this rift. Continuous struggles between government-loyal unionists and representatives who aim at transforming the unions will be discussed further in 4.2.3. 


\subsubsection{COOPERATION WITH INTERNATIONAL ORGANIZATIONS}

Asked about the role unions play in the face of economic changes (such as privatization), a union leader states: 'We have not prepared ourselves'. Employers have their international contacts. They compare and find ways how to maximize profit. 'But we as trade unions, who do we communicate with?' In his narration, the workers' representative emphasizes the importance of international union links in order to get to know 'what kind of strategies they use to defend in the world of today, what kind of strategies they use to educate workers'. One respondent already cooperates with a global union (the International Union of Food, Agricultural, Hotel, Restaurant, Catering, Tobacco and Allied Workers' Associations) - a strategy to solve conflicts especially with multinational companies. TUICO (Tanzania Union of Industrial and Commercial Workers) is seen as a positive example of bilateral exchange: leaders of this union forged alliances with their South African counterparts and were thus more successful in dealing with some South African investors in Tanzania. Larger regional networks, however, such as the Southern African Trade Union Coordination Council (SATUCC), the East African Trade Union Confederation (EATUC), the Trade Union Federation of Eastern Africa (TUFEA) and the Organization of African Trade Union Unity (OATUU) are depicted as 'loose' or inneffective. The reasons for this include the multiplicity of organizations, the co-existence of free and government-controlled unions (especially in TUFEA), the diversity and divergence of interests, and the lack of funds. For instance, the union federations of the East African Community countries have joined hands to review the process of regional economic integration and harmonization of labour laws. 'This is their organization, they have formed it, they were not forced by anybody, but they have failed to support it financially', an expert says. The cooperation with international partners is recognized as a means of realizing interests, but the budget of unions limits it.

'What we get from donors is strictly for training', an official from the apex organization complains, and elaborates on the inadequate financial resources for running the federation's offices. Several Western unions (e.g. LO-Norway, German DGB through Friedrich-EbertFoundation, Danish LO/FTF), development organizations (e.g. USAID, DANIDA) and the ILO have at times funded capacity building in occupational health and safety, labour rights, negotiating skills and other fields. The Danish organization DANIDA has offered the largest and most systematic support in training and non-training-related areas. An international expert explains why few development agencies are interested in continuous cooperation with trade unions:

... my idea about it is that it is not very sexy. It is sexy to work with HIV/AIDS; it is sexy to work with children and government bureaucracies. [...] I don't think working with the trade unions is something that seems a priority for many donors. Because also, if you look at the members of the trade unions, they are poor, but they are not the poorest in the country. [...] And many agencies [...] they want the poorest of the poorest. And also in many countries, if you have a liberal government, they are not very supportive of trade unions, either in their own countries or here.

Ideological positions together with trends in development funding have put unions in a fringe position with respect to international aid. Interestingly, respondents rarely referred to other possible or existing alliances (whether national or international) such as with NGOs. The only example mentioned is a co-operation with the South African NGO StreetNet - a point I will deal with in the following subchapter. 


\subsubsection{RECRUITMENT OF MEMBERS IN THE FORMAL AND INFORMAL SECTOR}

A top official of the federation regards the unions as weak, as only one third of those with formal employment are unionized. ${ }^{4}$ 'We have not managed to penetrate those areas where we could get more members'. Companies with high unionization rates are less common than those with smaller groups of members. Especially employees with above average salaries are underrepresented. For them, a union fee that is two percent of their salary is a sum they would rather keep in their pocket, another unionist says. But new members are not only crucial for financial reasons. 'If you represent many members, you are counted as someone who is actually doing something', one respondent states. Successful recruitment enhances the personal power of union representatives. At the time of this study, the apex organization and DANIDA were planning to support unions in developing new strategies for recruitment in the formal sector.

Since redundancies in the 1990 s reduced the membership size of some sectoral unions (see Chambua 2004), the informal sector was discovered for recruitment. The meaning of 'worker' (mfanyakazi) was redefined to include those who had been retrenched, a respondent explains. At the same time, the ILO declared its aim to organize the informal sector through cooperatives and trade unions. In the socialist era (when the focus was on parastatals only), small employees such as shoeshine boys were neglected, says another respondent. If they approached unions with labour matters they were told to solve them with local party representatives (such as ten cell leaders). Some union representatives now regard those who were turned away in the past as a huge potential. 'At present, whether you agree or not, the informal sector is our survival', a TUICO official says.

Union activities in the informal sector mainly consist of training and support for the formation of associations. The latter can initiate rotating saving funds, take part in tenders or represent workers' interests vis-à-vis local authorities. TUICO (Tanzania Union of Industrial and Commercial Workers) Dar es Salaam helped petty traders in the city's main market to organize professional groups which received union-sponsored courses in book-keeping and occupational health and safety. StreetNet, an international alliance of street vendors based in South Africa, trained some of the union leaders in charge of these activities. In one region of the Lake Zone (Mwanza), TUICO invited employees of small, often unregistered businesses for a discussion of labour laws and standards. Many of the participants later joined the union as paying members, according to a respondent. CHODAWU (Conservation, Hotels, Domestic and Allied Workers' Union) attempted to incorporate domestic workers and female food vendors. COTWU (Communication and Transport Workers' Union) addressed lorry, taxi and commuter bus drivers. In spite of these efforts and the significance attached by some officials to the inclusion of informal workers, success has been limited and criticisms harsh.

The informal sector is a typical 'ILO end of the year topic', when money is left over and union participants receive attractive per diems at seminars - thus being blocked for other duties with higher priority, a development partner criticizes. For him the ILO prematurely forces this topic on unions at a stage where the formal sector is not yet sufficiently organized. Besides, the union federation has not yet prepared an overall strategy on how to include the informal economy. Activities lack coordination with different unions competing for the same clientele or intruding into the ground of existing professional associations (such as VIBINDO founded by street hawkers in Dar es Salaam in 1995). Inadequate planning and insufficient financial and human resources make it difficult to address the informal sector. Features inherent in the sector 
further aggravate the situation: workers are generally poor, have low standards of education, and in some cases carry out illegal businesses. You need to buy them soda (a Swahili synonym for paying an incentive) and educate them, in order to get their attention, a respondent says. Some are so taken up by the day-to-day struggle for survival that the idea of embarking on a long-term process of change through unionization seems like an additional burden. On top of that, the informal sector has absorbed people who were retrenched during privatization of the parastatals. Many of them did not feel well represented by their unions in the past and have lost their trust in these organizations. The union image they harbour hampers recruitment.

\subsubsection{INVOLVEMENT OF MARGINALIZED MEMBERS}

If top union leaders step down, they create a vacuum, a development partner remarks. There is just a small pool of experienced union managers. Respondents mention two reasons for this: first, a restricted flow of information within the union management, and second, a low involvement of young and female members in running the organizations.

Concerning the first point, a federation official talks of meetings that take place only on paper. 'These unions are meant to be democratic. [...] Some leaders, as soon they have been appointed to their offices, don't call meetings any longer'. In some cases information is neither shared nor documented. Co-leaders are (intentionally or unintentionally) marginalized and have difficulties in making decisions from an informed stance. 'The documentation is certainly not very good in respect of what the trade unions are doing', an expert comments on how internal records are kept. The efficient management and handover of positions and processes is thus complicated. Another expert claims that in spite of financial problems the unions need to establish an effective public relations department to improve internal and external communication. This would create an increased sense of ownership among members.

Apart from the marginalization of members through a restricted flow of information, young and female members have too long been overlooked as candidates for leading positions. An expert: 'Young people are often regarded as unfit [...]. If you take for example the union offices, only few young people receive the opportunity to show how they could participate [...]. That is why many in the unions are old. [...] And they will retire. Now, who is prepared to go and take their places?' Another respondent views it as an ideology-laden generation conflict, in which elderly leaders who made their career under socialism do not want to hand over to younger members with post-socialist attitudes. In 2006, the federation amended its constitution to establish youth committees. One of the unions' development partners, the Friedrich Ebert Foundation, trains them in leadership aspects.

'One thing we are still working on that is still very weak, is gender equality. There are very few women in leading positions in the trade unions', an expert says. A female unionist gives three reasons as to why this is so. First, women are generally under-represented, as their employment is often more temporary or flexible than that of men. Second, as a result of their socialization women tend to lack the ability to speak and represent their interests in public. Third, in the fierce competition for leading positions female candidates are discriminated against. The respondent gives an example of an election for the apex organization in which a female candidate was rejected after being derided by her male competitors with the words: 'Ho! She is a woman. Is she going to represent us?' In the same meeting youth representatives had to be appointed. The only female candidate was again turned down with the argument that gender is irrelevant for the representation of young members. The respondent states that competition often 
puts women at a disadvantage - a situation that could be changed if solidarity across unions was strengthened. Those women who manage to secure positions in the federation have to do extra work to ensure that female interests are considered, an expert says. In union documents, male dominance in membership and leadership is acknowledged as a weakness. It is expected that a better integration of women and their interests would increase the 'representativeness and bargaining power' of the labour movement (TUCTA 2004: 75).

\subsubsection{IMPROVED EDUCATION FOR LEADERSHIP AND NEGOTIATION}

Education was not emphasized in the past. As a result, unions lack well-trained leaders, several respondents argue, and they stress the importance of raising educational levels to improve leadership and negotiation results. Some interviewees describe encounters in which they were overpowered by the rhetoric and knowledge some employers, government counterparts or even ordinary union members possess. 'Those you represent sometimes have a better understanding than you as leader', a respondent says, and attributes this to more travel exposure and new sources of information (such as the internet). Advanced technologies have changed the world of work for both employees and employers, but the unions are lagging behind, an official (in charge of education) remarks. An expert recounts how, after tripartite meetings (government, employers, trade unions), participants from the Ministry of Labour asked the union representatives to improve their negotiation skills. 'I view this as positive, meaning they could have left them in order to be on the better side of the negotiations', the expert concludes.

What role did unions assign to education in the past? A unionist recollects:

I started work under Organisation of Tanzania Trade Unions [the apex organization in the 1990s]. At that time and before it, education was meant to support the political system. The union was part of the party. There was a lot of ideology. The aim was to set you on the right political track. The union handbooks were full of political slogans: Freedom is work (uhuru ni kazi) and similar things. Today we don't serve the ruling party. It is more focused now on the workers' rights. [...] In the era of Jumuiya ya Wafanyakazi wa Tanzania [the sole socialist trade union between 1979 and 1991] the government was the biggest employer. One did not see any need to educate or train negotiating skills. On May Day, the president announced salary increases. These were automatic increments, the same for everybody. Today salary increases have to be negotiated individually. This creates a different situation.

Today union leaders have to be selected more carefully. We have to look at the logic of their argumentation, their willingness to defend, another respondent says. We are not ready to go back to a mere repetition of what others on higher hierarchical levels have said. Although my interview partners agree on the importance of raising educational standards, they hold different ideas of what education should include. An official describes poor education as being related to a reluctance to make decisions and take over responsibility. 'We had this education of having decisions made for us. But education in the sense that you learn how to make decisions by yourself, we haven't had it. [...] But as we haven't had it, [...] we do not take decisions. You look for someone to come and do it for you'. The passive attitude of leaders is also attributed to an incomplete understanding of labour laws 
and wider economic, social and political processes. 'Our education today has to be more aggressive. You have to bring up arguments. Negotiations are tough. You need enough information', a leader says. An expert sees further shortcomings: union leaders' restricted knowledge of national and global interrelationships results in a weak concept of how unions should act. "There are laws being passed, but TUCTA as a stakeholder does not react. And if you ask them, they say, "We haven't been invited". But in the changed economy we have now, you don't wait to be invited by somebody. You watch out where your rights are being infringed upon, maybe you can give advice or take part'. Examples mentioned are the increase in commuter bus fares by the transport authority (which threatened to cut down people's income), and the discussion of economic partnership agreements. In both cases, the expert claims, unions initially did not realize how these topics would relate to them and thus did not react. Another respondent views the unions as not necessarily having a lack of formal education, but a lack of reflection and of the ability to correct their position. To summarize: respondents mention poor decision-making, a passive attitude, an incomplete understanding of labour-related matters, and low levels of reflection as obstacles to successful leadership and negotiations. Some of these obstacles are seen as survivals of the unions' socialist past.

What is the effect of capacity-building measures partially funded by development partners? An expert emphasizes the positive outcomes of these trainings but views them as insufficient with regard to membership size and structure. Her example is DANIDA, which trained all regional union secretaries in the new labour law. 'Now, if you have already trained those people on the regional level, how will this education trickle down to the district levels and the workplaces? That is where the problem lies', she says. Only few sectoral unions make sure that training input is disseminated to lower levels. Financial restrictions and understaffing are the cause, several respondents explain. An additional cause could be that some unionists reject 'modern education' in general. The regional secretary of a sectoral union states that: 'Some elderly union leaders also regard education as not important. They themselves do not have education. But they run the unions according to their habits, even against the law. They act by following the motto: We have been here for a long time. We have survived several radical changes. It will work without modern education'. For this respondent, the question of education dissemination is linked to intergenerational conflicts within the union leadership.

This section (4.1) outlined strategies respondents see as strengthening the position of unions. In the following section (4.2) I will shift my attention to general constraints unionists encounter either within their organizations or in the external environment.

\subsection{Restrictions to Realizing Workers' Interests}

Obstacles to realizing workers' interests are described in four areas: first, cooperation within or between the unions is in part marked by strong competition. Second, finances are inadequate and certain internal organizational processes are inefficient. Third, detachment from the government is incomplete. Fourth, unions have to operate in a society that is largely

characterized by low levels of education and income. In what follows I will elaborate on these points. 


\subsubsection{COMPETITION WITHIN/BETWEEN UNIONS}

Respondents mention conflicts both within unions and within their apex organization, as well as between sectoral unions. These conflicts become most visible when new leaders are elected. An expert speaks of 'a lot of power struggles [...] and corridor negotiations' behind the federation's formal façade of democratic votes. Coalitions are often more based on personal interests than on different positions with respect to how the unions should be managed, another expert observes. 'There is this selfishness, instead of saying: Folks, we are here to represent the workers. The welfare of the workers has to come first. [...] They have not yet understood that if you join hands you strengthen your power. Still it is this: I want to be the General Secretary. I want to be the chairperson of the union'. A union leader confirms what the experts describe: 'There are people who have joined the unions for their own interests, not for the interests of the majority. (...) Someone of this kind does not need the union, he needs management, he needs leadership'. In some cases this has caused a fragmentation of unions, with new workers' organizations being established to compete for the same clientele. Competition within unions is then turned into competition between same-sector unions.

Personal interests involved in the struggle for positions may be of different kinds. One respondent speaks of candidates who run for leadership because they have not succeeded in finding attractive employment elsewhere. Others make a lot of 'harmless noise' in the newspapers in order to be selected for parliament. In fact, high union positions serve as a springboard for political careers and for well-paid board memberships. An expert about union leaders: 'Many vie to be chosen for various national boards. Here you cannot find a person who is very strong. Labour matters are being fooled around with. You dance to the tune of those who pay'. According to this expert, some ambitious unionists neither raise nor fight for controversial topics, as conflicts (especially with government representatives) would lower their career chances. Yet another kind of personal interest brought up in the interviews is access to the unions' financial resources. High-ranking officials are said to squander and embezzle funds, resulting in a loss of credibility among ordinary members. The extent of this problem, however, remains vague.

Turning from internal competition to competition between unions, one development partner says: 'We have a lot of demarcation problems between the unions'. In the liberalization process, some sectoral organizations have deliberately added 'and Allied Workers' Union' to their names. 'They end by saying "allied workers", which they interpret as meaning that they can take whatever they want', the expert states. He considers TUICO (Tanzania Union of Industrial and Commercial Workers) as one of the strongest and most competitive unions, 'giving much better service to their members. So it is easy for them to attract people from other unions'. The apex organization seems to have a mediating role when conflicts arise. According to the expert, TUICO was told to recruit workers who are not yet unionized, instead of organizing those who are already organized'. Two other respondents describe how at various places unions have competed for the workforce of one and the same company. The fierce competition is not only explained by the need to gain more fees and power, it is seen as intended by the government. The new labour law allows employees to join whichever union they prefer. 'The government has liberalized, divided and thus weakened the trade unions', an official claims. In fact, a total of 317,716 workers are organized in 14 sectoral unions ranging from about 150 to 130,000 members (TUCTA 2004: 35). A lack of unity is also expressed by the fact that some unions have been unwilling to pay their contributions to the federation. Individual unions are supposed to transfer $5 \%$ of their membership fees to the apex organization. A high-ranking leader about 
unpaid contributions: 'This makes the federation weak. [...] We therefore feel that solidarity between unions has not yet reached the level needed'.

\subsubsection{ORGANIZATIONAL AND FINANCIAL SHORTCOMINGS}

Financial problems are not only seen as restricting solidarity, respondents mention them in combination with organizational inefficiencies as general obstacles to realizing power. Asked if the unions have gained or lost power since liberalization, an expert states: 'I don't think they really had any power under the old system. [...] And I won't say they have gained a lot of power, because they are still not very rational in the way they are working'. The respondent sees a need to train unions in 'planning, advocacy and research, so they have the documentation needed to back up their political statements'. With regard to planning, a lack of coordination is criticized. The four departments of the apex organization act as independent units, each having their own work plans without matching activities with each other and the overall strategy. Internal educational measures for instance 'are to a large degree ad hoc activities' and do not follow a training system or long term plan, the above expert claims. Other shortcomings mentioned by development partners are: delayed or insufficient report writing to donors, a lack of internal documentation and poor research about labour matters in general. However, these problems should not be overgeneralized. Some unions follow detailed strategic plans with objectives being discussed at weekly or monthly meetings. As a TUICO (Tanzania Union of Industrial and Commercial Workers) leader puts it: the liberalized unions depend to a large extent on membership fees. They have to serve their members well. This is only possible through efficient organization.

Shortcomings in management are in part attributed to limited financial resources and to the understaffing which results from it. Both at the level of the federation and at the level of sectoral unions, respondents were concerned with the question as to how potential and existing members could be reached. An official in the federation speaks of the need 'to reach even the most remote areas [...] but we are constrained by funds'. Consequently, unions concentrate their activities in Dar es Salaam and other larger cities. Summarizing the respondents' accounts, the relationship between cause and result remains unclear: some claim that organizational inefficiency produces a limited income and thus restricted power. Others state that a limited income leads to low staff capacity (in terms of numbers and capability) and thus to organizational inefficiency.

\subsubsection{INCOMPLETE DETACHMENT FROM THE GOVERNMENT}

Contradictory features mark the relationship between unions and the government. On the one hand, workers continuously engage in struggles with the government as their employer (see 4.1.1). On the other hand, a considerable number of senior unionists are still closely attached to the government and the ruling party - this being a result of their work history in the former socialist trade union. Part of these entanglements is the question as to what role unions should play in the political system. Below, I will first look at the continuity of union ideology and personnel, and then at the discussion on how labour matters should be represented in the political arena.

Officials and experts come up with different judgements concerning the relationship between unions and the government. A federation leader expresses gratitude that the Tanzanian state acknowledges the importance of trade unions. 'We are not seen as an opposition party. [...] We are grateful that the government has very often listened to us'. He describes strikes as a 
threatening tactic, but finally everybody returns to the negotiation table. Another unionist describes May Day as an occasion to confirm positive relations between workers, employers and the government. It is exactly this emphasis on harmony that is criticized by development partners. An expert states that: 'These union officials, if you see them meeting with the government, with the Ministry of Labour, but also with the employers, you always have the funny feeling that they are a club, as if they had the same interests, instead of diametrically opposed interests'. Some measures introduced by the government have adverse effects on the workers, but are not addressed by unions, 'because they feel they are still closely affiliated to the CCM [the ruling party]', another development partner says. The continuity of staff in part results in overly friendly attitudes towards the government and a low level of service provision towards members. Union leaders' long-established habits stand in opposition to fundamental changes in the political and economic environment. Any transformation, however, has to come from within the unions, the same expert concludes. Another expert: 'We need to have the old generation out before we can get full compliance with the new situation'.

Despite continuous government loyalty by part of the 'old generation', many union constitutions forbid leaders to be actively involved in party politics. Unionists chosen for positions in the government or in political parties have to resign from labour representation. In the liberalization process, such clauses were formulated to prevent the ruling party from controlling the unions. Some respondents view this regulation as resulting in insufficient consideration of labour matters in the political arena. Changes in union constitutions are therefore planned, or have already been made. In line with this is the attempt by union leaders to use voting power as a new weapon. Approaching the general election in October 2010, several officials pressed workers not to vote for the ruling party if it would not improve civil servants' salaries. On May Day 2010, workers in Dar es Salaam carried a banner saying, 'The 2010 election will be the solution to the workers' problems'. For the first time, the Tanzanian president and government leaders were not invited to the rally. The acting secretary of the union federation announced that senior unionists would run for parliamentary seats to represent workers' concerns. This contradiction between opposition to and at the same time incomplete detachment from the government marks the transformation unions are currently going through.

\subsubsection{POVERTY AND LOW EDUCATIONAL STANDARDS}

Poverty, unemployment and low educational standards are seen as restricting the potential for unionization. 'In a country in which the unemployment rate is so high, it is generally very difficult to push for decent conditions. [...] Most people don't have a job and would like to work under whatever conditions', a development partner says. Several respondents describe companies in which applicants are given employment on condition that they do not join a union. When union representatives visit, staff members protect their employers by claiming to have decided voluntarily against joining a union. Poverty, and the fact that large families often depend on few wage earners, increase the power employers have over their workers.

Financial need and a lack of education produce fear and a low level of self-confidence, an official states. The labour laws are there, but many workers are not familiar with them or choose to ignore them. Deference to political authorities is common, and hinders union activities. The official recounts how he discussed workers' rights in the media. Later the Tanzanian president made a counter-statement. Some workers accepted the latter without question. 'Even if the president talks nonsense, the workers say: The president has spoken. That's it'. Others have found 
access to employment through fake certificates, the respondent continues (see Machira 2008 for massive forgeries in the educational sector). They do not take action against their employers, as their personal files would be scrutinized more closely. All in all, this leads to the fundamental question of how union power is backed up. You may have the authority to speak on behalf of your members or to represent labour matters in general, but is there a supporting majority behind you, the official asks. A restricted awareness of labour rights (and human rights), together with a low density of civil society organizations engaged in this field, and inadequate networking among them, weaken and atomize unions in their struggles.

In the above section (4.2) I have presented factors which union leaders and development partners view as limitations to realizing their goals. In what follows, I will discuss how these findings and historical accounts relate to Piven and Cloward's (2000) concept of power repertoires. I will start with changes in the repertoire of collective action, and then proceed to look at the power potential unions have.

\section{Discussion: Power Repertoires and Transformation}

In the 1920s, Tanzanian workers developed a repertoire of letters, petitions and protests that furthered the complaints of smaller groups. When strikes were added to the strategies, action emerged on a national scale. As a result, the colonial government attempted to silence the labour movement through official recognition and institutionalization - without success. The independence movement and labour movement joined hands to fight foreign capital and government - temporarily de-emphasizing differences in the aims they pursued. After independence, the ruling party used its political power to control its former partner and to restrict their repertoire of collective action. Since legal measures made strikes almost impossible, workers had to develop new ways to make themselves heard, such as locking out managers. Another common strategy was to turn labour grievances into political affairs by accusing managers of capitalism, nepotism or tribalism. At the same time (and not viewed as a contradiction), workers employed their ethnic and kin ties with high-ranking party officials to limit the power of managers in state-owned companies. Fischer (2006) details how in the 1970s factory workers (assisted by party cadres) chased away their personnel manager, who they felt to be an unfair leader and overly powerful patron (see Nyalali 1975: 207-208). Only a few years later, workers replaced the one big patronage they had fought with their own smaller ones, which they used to impact upon management decisions (Fischer 2006: 112-117). Both workers and managers kept each other in check through patron-client systems.

The liberalization of the unions in the 1990s has created a situation in which the repertoire is being revised while established patterns persist. Some unionists cling to friendly relations with government counterparts. Others have revived strikes - a successful instrument in the unions' past. A novelty is negotiations. Of little importance in the socialist era, they are now in some areas enforced upon unions by external actors more than they are actively sought. An example is the government's (even if somewhat erratic) summoning of the Labour Advisory Board (since 2004: Labour, Economic and Social Council). Unions can use this tripartite national body to impact upon policy formulation and review, but show little initiative to do so (Friedrich Ebert Foundation 2003: 30; for additional examples see Mukandala 1999: 43-44). Mlawa, Mwisomba and Semkiwa (2003) describe the unions' relationship with the government as one of mutual mistrust resulting in a lack of impulse to cooperate, such as in the development 
of the Poverty Reduction Strategy Papers (2003). The ILO trained members of the unions' apex organization to engage in the national poverty reduction strategy process and in social dialogue (see Casale and Buckley 2006: 354). In a recent study, McQuinn finds a strong interest and willingness on the part of union leaders to participate in negotiations (2009). The mobilization of workers' votes against the government - a means union officials have recently introduced - is another case. This strategy is in crass contrast to the past, in which unions were part of the oneparty apparatus and thus always in support of the government. Whether it will grow into a successful and long-lived weapon, remains to be seen. In spite of these changes, hidden forms of resistance remain permanent parts of the repertoire. Go-slows, for instance, were common under socialism and are still used today, such as in confrontations between teachers and the government. A detailed exploration of hidden repertoires is overdue for Tanzania. The chart below captures the revision of the repertoire in the transition from the socialist to the post-socialist era. It should not be read as showing a radical break, but rather as depicting the outcome of continuous processes that are subject to creativity and resistance to change.

Table 1: Repertoire of the Socialist and Post-Socialist Era

\begin{tabular}{|l|l|}
\hline Socialist Corporatist Era & Post-Socialist Liberalized Era \\
\hline Ideological Struggles & Strikes \\
Patron-Client Systems & Negotiations \\
Lock-Outs & Workers' Votes \\
Go-Slows & Go-Slows \\
\hline
\end{tabular}

Turning to the power potential Piven and Cloward (2000) distinguish from strategies, respondents saw different factors as increasing or decreasing their power. Tanzania's introduction of a multi-party democracy, and the detachment of unions from the still ruling party, together with the economic changes the country has undergone (including the massive privatization of parastatals), have had an impact on the labour movement. Moreover, additional factors, beyond the immediate economic and political situation, determine the power potential of workers. Whether labour power in general has grown or waned is difficult to assess, as became clear from the unionists' voices. After reorganizing the respondents' accounts in the light of this concept, I can identify five factors that are seen as diminishing union power: the incomplete detachment from the government, organizational and financial shortcomings, the division of workers according to age and gender, internal competition within the labour movement, and poverty and low education in the general population. Unionists and experts assign different weight to these points. Development partners view harmonious labour relations between employers, government and union officials as more problematic than many unionists in the sample. The former interpret an emphasis on harmony as deference to those in power, and a poor awareness of power and conflict. Some unionists only gradually loosen their attachment with the government as they mourn over their lost financial security. In the past they were less dependent on membership fees, since membership was mandatory and the unions' budget formed part of the party's budget. Union officials therefore tend to see financial restrictions as causing organizational shortcomings, 
whereas experts argue the other way round. Divisions according to age and gender serve to maintain gerontocratic and patriarchal leadership structures. Although union documents identify these structures and the low number of female members as limiting their power and representativeness (see TUCTA 2004), only experts and female unionists raised this point. The segregative power of male leaders stands in the way of those who want to develop a stronger power potential through integration. Further divisions arise in the competition within and between unions. In the struggle for leadership positions and new members, individual and/or collective interests collide. Moreover, the government stimulates union pluralism - a strategy to contain labour power (see Valenzuela, 1989). Finally, poverty, patterns of deference and low educational standards in the general population create a power vacuum for union leaders. They are not backed up by people who - though not union members - sympathize with labour ideas. Civil society is nascent and marked by a lack of alliances. The unions still see themselves as membership and workplace organizations, and not as one social movement among others working for broad social change.

Actions and conditions within and beyond the unions' control threaten their potential. But respondents also mention ways to expand their power: the recruitment of new members, training of union leaders, and international cooperation. In spite of disagreement about where to recruit members, mobilization is expected to increase pressure on employers and the government, add income, and strengthen belief in the righteousness of labour struggles. A broader understanding of labour issues is seen as a precondition for successful negotiations in the liberalized era and would produce an increased awareness of power and the potential to actualize it. Some development partners therefore assign priority to capacity building in their funding policies. Apart from providing training and restricted financial aid, international cooperation is limited. Although the exchange of ideas could help to improve or devise means of collective action - a new part of the repertoire (maybe) consisting of transnational collective action itself this does not (yet) apply to Tanzania. For this reason, the general applicability of Cohen and Rai's model (2000) has to be questioned. After the end of socialism, Tanzanian unions reverted to the repertoire the authors relate to the national era (strikes, public rallies). Transnational union links, as well as links with other civil society organizations, are still weak (see McQuinn 2009). Social movement unionism and global labour solidarity are neither strong ideas nor reality in Tanzania.

Piven and Cloward's framework allows an interpretation of the data based on two concepts: means of collective action, which form the repertoire, and power potential, which is created by institutional arrangements. The broad character of these concepts is useful for inductive explorative research, but would require refinement after further studies. For instance, factors diminishing or increasing power potentials and their interrelationship could be identified and theorized in a more detailed fashion. A comparison of workers' repertoires (and similarly employers' repertoires) in different contexts would help to discern general and specific features. In addition, future research should focus more on the diverse actors involved in (or excluded from) collective action and their construction of overlapping solidarities. This becomes clear where Piven and Cloward claim that the repertoire (and not the power potential!) is 'shaped by multiple relations beyond the particular power relations at issue' (2000: 414). Here two aspects have to be looked into: first, assuming that 'particular power relations' are class relations, further investigation is needed into how far class is actually at the core of the relations, while other relations go beyond class and are thus separable or of minor importance. If Tanzanian unions mainly represent male workers, what is the relationship between class and gender? The same question has to be raised for ethnicity and kinship. In a case study, Tanzanian workers used 
ethnic or kin ties to realize labour interests and depicted them as workers' participation. However, only co-ethnics or kin were made part of the patron-client systems (Fischer 2006). Which of the criteria was at the core - class, kinship, ethnicity or all of them? Second, not only the repertoire is determined by multiple relations, but also the power potential. The specific constellation of social relations and the power inherent in them bear on both the potential and the means of collective action. At this point, the analytical framework needs clarification.

\section{Conclusion}

This article explores how Tanzanian unionists and their international partners describe their repertoire and power potential. Both repertoire and potential develop in a constant and sophisticated interplay between manifold social groups, as well as with strategies used by government and employers in favour of or against workers. It is within this broader context that inventories of collective action are forged. Periods of radical transformation - such as Tanzania's turn away from socialism - challenge the established order and provide a unique opportunity to study unionists' perspectives on the past and present and their willingness or resistance to change. However, future studies should broaden the inquiry from a focus on means and power potentials to the question of what kinds of solidarities actors construct. For Tanzania it needs to be shown how the attempts at including more women, youth and informal workers in the unions will affect power relations and the development of new forms of collective action.

\section{NOTES}

${ }^{1}$ This article focuses on the labour movement in mainland Tanzania. Historical and recent developments on the islands of Pemba and Zanzibar, which have their own individual unions and federation, are not considered.

${ }^{2}$ See late president Julius Nyerere's speeches 'Malengo ya Kazi' (The Objectives of Work) and 'Kuutafuta Usawa' (In Search of Equality), both published by the National Union of Tanganyika Workers (1977).

${ }^{3}$ The latest Integrated Labour Force Survey of 2006 indicates agriculture as accounting for $75.1 \%$ of the employed population (aged 15 years and above), followed by the informal sector with 10.1 $\%$, private formal employment with $8.6 \%$, central/local government employment with $2.6 \%$ and employment in parastatals with $0.4 \%$ (The United Republic of Tanzania 2007: 16).

${ }^{4}$ Assens and Jensen speak of a unionization rate of $26.5 \%$ in 2003 (2003: 55). 


\section{REFERENCES}

Assens, J. and Jensen, K. (2003) Profile of the Labour Market and Trade Unions in Tanzania. Copenhagen: LO/FTF Council, Danish Trade Union Council for International Development Cooperation.

Brodkin, K. (2010) 'Concluding Thoughts', in P. Durrenberger and K. Reichart (eds) The Anthropology of Labor Unions (pp. 221-224). Boulder: University Press of Colorado.

Casale, G. and Buckley, G. (2006) Social Dialogue and Poverty Reduction Strategies. Geneva: ILO.

Chambua, S. (2004) 'Impacts of Globalisation on Trade Unions in Tanzania', Tanzania Journal of Development Studies 5(1): 1-16.

Chambua, S. (2002) Democratic Participation in Tanzania. The Voices of Workers' Representatives. Dar es Salaam: Dar es Salaam University Press.

Cohen, R. (1980) 'Resistance and Hidden Forms of Consciousness Amongst African Workers', Review of African Political Economy 19: 8-22.

Cohen, R. and Rai, S. (2000) 'Global Social Movements. Towards a Cosmopolitan Politics', in R. Cohen and S. Rai (eds) Global Social Movements (pp. 1-17). London: The Athlone Press.

Durrenberger, P. (2007) 'The Anthropology of Organized Labor in the United States', Annual Review of Anthropology 36: 73-88.

Durrenberger, P. and Reichart, K. (eds) (2010) The Anthropology of Labor Unions. Boulder: University of Colorado Press.

Erem, S. and Durrenberger, P. (1997) 'The Way I See It: Perspectives on the Labor Movement from the People in It', Anthropology and Humanism 22(2): 159-169.

Fischer, G. (2003) 'Welfare and Security: The Impact of Privatization on Quasi-Familial Relationships in a Tanzanian Factory', in H. D'Almeida-Topor et al (eds), Le Travail en Afrique Noire (pp. 331-346). Paris: Karthala.

Fischer, G. (2006) Unsere Fabrik - Unsere Familie. Vorstellungen von Verwandtschaft und Familie in einem tansanischen Industriebetrieb vor der Privatisierung und danach. Berlin: Lit.

Friedrich Ebert Foundation (2003) Trade Union Survey 2003. Unpublished Working Paper. Dar es Salaam.

International Confederation of Free Trade Unions (2006) 'Internationally Recognised Core Labour Standards in Tanzania. Report for the WTO General Council Review of the Trade Policies of Tanzania'. Available at: 
www.icftu.org/www/pdf/corelabourstandards2006tanzania.pdf [accessed 02 January 2011].

Komba, S. (2010) 'It's Time the Govt End its "Marriage" with Rites', Sunday Citizen (Dar es Salaam). 4 April, p. 23.

Machira, P. (2008) 'Massive Forgery in Teachers Colleges', The Citizen (Dar es Salaam). 2 August. Available at: http://www.thecitizen.co.tz/newe.php?id=7121 [accessed 12 November 2009].

Masanja, P. (1990) 'Industrial Workers and the Politics of Incorporation', in N. O'Neill and K. Mustafa (eds), Capitalism, Socialism and the Development Crisis in Tanzania (pp. 207232). Aldershot: Avebury.

McQuinn, M. (2009) 'Trade Union Ideologies and Poverty Reduction: Should Tanzanian Trade Unions Move Towards "Social Movement Unionism" in Order to Become More Effective Players in the Poverty Reduction Strategy Paper (PRSP) Process?', in Conference Proceedings of the Norwegian Association for Development Research, Annual Conference 2009, University of Agder.

Mihyo, P. (1983) Industrial Conflict and Change in Tanzania. Dar es Salaam: Tanzania Publishing House.

Mlawa, H. et al. (2003) 'Trade Unions and Poverty Alleviation Initiatives in Tanzania', in M. Mwamadzingo and D. Saleshando (eds), Trade Unions and Poverty Alleviation in Africa (pp. 67-78). Geneva: ILO.

Mukandala, R. (1999) 'Trade Unionism in Tanzania: The Case of the Tanzania Federation of Trade Unions (TFTU) and Government', Civil Society and Governance Programme. Available at: http://www.ids.ac.uk/ids/civsoc/final/tanzania/Tan2.doc [accessed 14 August 2005].

Musoke, I. (1996) 'The Social Impact of Structural Adjustment Programmes on the Working Class: Implications for Employers and Industrial Relations in Tanzania', H. Moshi and A. Maenda (eds), Socio-Economic Transformation in Tanzania: The Role of Employers (pp. 4577). Dar es Salaam: Friedrich Naumann Foundation.

N.A. (2011) 'May Day Anti-Climax', The Citizen (Dar es Salaam). 2 May, pp. 1-2.

N.A. (2011) 'TUCTA Yaitega Serikali', Raia Mwema (Dar es Salaam). 27 April - 3 May, p. 4.

Nyalali, F. (1975) Aspects of Industrial Conflict. A Case Study of Trade Disputes in Tanzania 19671973. Kampala: East African Literature Bureau.

Nyerere, J. (1977) 'Malengo ya Kazi', in National Union of Tanganyika Workers (ed), Wafanyakazi na Ujamaa Tanzania (pp. 17-22). Arusha: Tanzania Litho. 
Nyerere, J. (1977) 'Kuutafuta Usawa', in National Union of Tanganyika Workers (ed), Wafanyakazi na Ujamaa Tanzania (pp. 34-40). Arusha: Tanzania Litho.

Otanez, M. (2010) 'The Tobacco Trap: Obstacles to Trade Unionism in Malawi', in P. Durrenberger and K. Reichart (eds) The Anthropology of Labor Unions (pp. 189-209). Boulder: University Press of Colorado.

Piven, F. and Cloward, R. (2000) 'Power Repertoires and Globalization', Politics \& Society 28(3): 413-430.

Shivji, I. (1986a) 'Introduction: The Transformation of the State and the Working People', in I. Shivji (ed), The State and the Working People in Tanzania (pp. 1-15). Dakar: Codesria.

Shivji, I. (1986b) Law, State and the Working Class in Tanzania. Dar es Salaam: Tanzania Publishing House.

Spradley, J. (1979) The Ethnographic Interview. New York: Holt, Rinehart and Winston.

The United Republic of Tanzania (2007) Key Findings for Integrated Labour Force Survey (ILFS), 2006. Dar es Salaam: National Bureau of Statistics.

Tilly, C. (1984) 'Social Movements and National Politics', in C. Bright and S. Harding (eds), Statemaking and Social Movements. Essays in History and Theory (pp. 297-317). Ann Arbor: The University of Michigan Press.

Tilly, C. (1993) 'Contentious Repertoires in Great Britain 1758-1834', Social Science History 17(2): 253-280.

Trade Union Congress of Tanzania (TUCTA) (2004) Trade Union Membership Profile in Tanzania. Dar es Salaam: TUCTA.

Ulimwengu, J. (2010) 'Kikwete Goes Macho with Workers, Trade Unionists, but his Target is Wrong', The East African 10-16 May, p. 17.

Valenzuela, S. (1989) 'Labor Movements in Transition to Democracy: A Framework for Analysis', Comparative Politics 21(4): 445-472.

\section{BIOGRAPHICAL NOTE}

GUNDULA FISCHER is Lecturer in Cultural Anthropology at Tumaini University, Iringa, Tanzania. Her area of specialization is in the Sociology and Anthropology of Work and Organizations. More specifically, her work has concentrated upon kinship, patronage and 
paternalism in a factory in Dar es Salaam, recruitment methods and labour market segmentation in Mwanza (Tanzania's second largest town), and the transformation of the Tanzanian trade unions. Currently she is involved in a research project on gender and employment in the hospitality industry. 